\title{
COST-EFFECTIVENESS ANALYSIS FOR HPV MITIGATION STRATEGIES IN THE REPUBLIC OF MOLDOVA BASED ON INFECTIOUS DISEASE MODELLING
}

\author{
Andrzej JARYNOWSKI ${ }^{1}$, PhD Candidate \\ Moldova State University, Chisinau, Republic of Moldova \\ Interdisciplinary Research Institute in Wroclaw, Poland
}

\author{
DOI: https://doi.org/10.36004/nier.es.2019.2-05 \\ JEL Classification: I18, 033, C32, C53, C54, C63 \\ UDC: 614.2: 618.1-006.52-08
}

Human papillomavirus (HPV) is a sexually transmittable virus infection, which is a-necessary risk factor for developing cervical cancer, first killer for working women in Moldova. Since 2018 Moldova has modified the screening program and the vaccination program (mainly funded externally). To assess the performance of the mitigation policy we propose the cost-effectiveness analysis according to 2 already implemented strategies. (1) Vaccination of a single age-cohort, although vaccinating a single cohort may not have a substantial effect in other countries with distinct socio-economic situation. (2) Transition to more technologically advance screening ecosystem (changing from Romanowski to Pap smear), which might not necessary be cost-efficient in low resource settings (if GDP per capita doesn't grow substantially at the same time). (1) We verified that single cohort vaccination is both cost-beneficial (total costs reduction will balance intervention costs around the year 2040) and cost-efficient (with incremental impact in 20 years perspective on the level of 2300 EUR/QALY). Moreover, we found out that single year cohort is more beneficial than 5years cohort vaccination scenarios in our mathematical model. This behaviour could be explained by a transitional situation in Moldova (HPV epidemic is near outbreak threshold), still small changes of model parameters and initial conditions could cause strong effect in the epidemiology. However, a definitive answer cannot be given with the chosen methodology. (2) Transition between Romanowski -> Pap smear cytology in screening benefits unquestionably in epidemiology e.g. due to a higher specificity. However, further maintenance and higher procedure costs could exceed treatment costs, hence intervention costs would gather an unacceptable share of national resources that are limited and that are dedicated to public health.

Keywords: computational social science, epidemiology modelling, cost-effectiveness analysis, HPV and cervical cancer.

Virusul papiloma uman (Human Papilloma Virus sau HPV) este o infecție virală sexual transmisibilă și un factor de risc pentru dezvoltarea cancerului de col uterin - cel mai frecvent tip de boli oncologice la femeile apte de muncă din Republica Moldova. Din 2018, în Republica Moldova a fost modificat programul de screening și programul de vaccinare (finanțat în principal din exterior). Pentru a evalua performanța politicii de atenuare, propunem analiza cost-eficiență în conformitate cu 2 strategii deja implementate. (1) Vaccinarea unei singure cohorte de vârstă, deși vaccinarea unei singure cohorte nu poate avea un efect substanțial în alte țări cu o situație socio-economică distinctă. (2) Trecerea la ecosistemul de screening avansat din punct de vedere tehnologic (schimbarea de la romanowski la frotiul Papanicolau), care ar putea să nu fie necesar din punct de vedere al costurilor în cazul resurselor scăzute (dacă PIB-ul pe cap de locuitor nu va crește substanțial în acel moment). (1) Am verificat faptul că vaccinarea cu o singură cohorta este benefică atât din punctul de vedere al costurilor (reducerea totală a costurilor va echilibra costurile de intervenție în jurul anului 2040), câtși costurile (cu un impact incremental în perspectivă de 20 de ani la nivelul de 2300 EUR / QALY). Mai mult, am aflat că o cohortă unică este mai benefică decât vaccinarea continuă în modelul nostru matematic. Acest comportament poate fi explicat printr-o situație de tranziție în Republica Moldova (epidemia de HPV este aproape de pragul izbucnirii), totuși modificările mici ale parametrilor modelului și condițiile inițiale ar putea avea un efect puternic în epidemiologie. Cu toate acestea, nu se poate da un răspuns definitiv cu metodologia aleasă. (2) Tranziţia între romanowski -> citoplasmă Papanicolau în

1 @ Andrzej JARYNOWSKI, $₫$ ajarynowski@gmail.com 
screening beneficiază, fără îndoială, de epidemiologie, de ex., datorită specificității mai mari. Cu toate acestea, întreținerea ulterioară și costurile de procedură mai mari ar putea depăși costurile de tratament, prin urmare, costurile de intervenție ar aduna cote inacceptabile în întreaga gamă de resurse naționale limitate dedicate sănătății publice.

Cuvinte-cheie: științe sociale, calcul, modelare matematică, analiza cost-eficiență, HPV și cancer de col uterin.

Вирус папилломы человека, или ВПЧ, передаваемый половым путем, является одним из факторов риска для развития рака шейки матки - одного из самых распространенных типов онкологических заболеваний у женщин трудоспособного возраста в Республике Молдова. С 2018 года в Республике Молдова была изменена программа скрининга и программа вакцинации, финансируемые в основном из внешних источников. Для оценки эффективности политики смягчения последствий был предложен анализ экономической эффективности в соответствии с двумя уже реализованными стратегиями. (1) Вакцинация одной возрастной группы, хотя вакцинация одной когорты может не иметь существенного эффекта в других странах с отличающейся социально-экономической ситуацией. (2) Переход к более технологически продвинутой системе скрининга (переход от мазка Романовского к Пап-мазку), который может быть необязательным с точки зрения затрат в условиях ограниченных ресурсов (если ВВП на душу населения не будет одновременно существенно расти). Результаты исследования показали: (1) вакцинация одной когорты выгодна с точки зрения затрат (снижение общих затрат позволит сбалансировать расходы на профилактику примерно к 2040 году) и эффективна с точки зрения затрат (с дополнительным воздействием через 20 лет на уровне 2300 евро / QALY). Более того, мы обнаружили, что в нашей математической модели вакцинация одиночной когорты более полезна, чем непрерывная вакцинация. Такая ситуация может быть объяснена переходной ситуацией в Республике Молдова (эпидемия ВПЧ близка к порогу вспышки), хотя небольшие изменения параметров модели и начальных условий могут оказать сильное влияние в эпидемиологии. Однако использованная методология не позволяет дать однозначный ответ. (2) Переход от мазка Романовского к цитологическому Пап-мазку при скрининге, несомненно, полезен в эпидемиологии, например, из-за более высокой специфичности. Тем не менее, дальнейшее обслуживание и более высокие затраты на процедуры могут превысить затраты на лечение, поэтому затраты на профилактику составили бы недопустимо высокую долю расхода ограниченных национальных ресурсах, предназначенных для общественного здравоохранения.

Ключевые слова: вычислительные социальные науки, Эпидемиологические моделирование, анализ экономической эффективности, ВПЧ и рак шейки матки.

INTRODUCTION. The Republic of Moldova has recently started a battle with health problems as sexually transmittable diseases and cancers, but due to financial crisis, lack of program coordination, partly because of a lack of experience, has still a high morbidity and mortality. From ECDC (European Centre for Disease Prevention and Control) reports [1, 2012] Moldova is a European country with almost highest cervical cancer risks and classified by WHO (Wold Health Organization) in the field of sexually transmitted diseases at the level of countries of the third world [2, 2012]. Additionally, we observed political transformations and beginning of social norm changes in Moldova [3, MOCANU, V., DUMBRAVENAU, A., 2013] as increase of sexuality patterns in number of sexual partners (second demographic transition or post-modernist revolution). We would like to model multi-faceted transmission of diseases [4, ARBYN, M. et al., 2009] in the context of determining the best epidemiological control according to budget possibilities. The optimal preventive guidelines are known: cervical screening practice, teenagers' vaccination and sexual education. In developed countries mitigation strategies are so successful to think even about disease's eradication soon [5, BRISSON, M. et al., 2016]. However, costeffectiveness of the described intervention in resource limited setup is still unknown with high uncertainty in HPV vaccination, screening, and cancer treatment costs. The purpose of this research is to prepare the costeffectiveness analysis of new screening and vaccination guidelines already implemented in Moldova. 
This paper describes epidemiological and financing trends on HPV and cervical cancer in Moldova according to a new program launched in 2018. Around 800k EUR in 2017-2018 was spent on capacity building in new screening technology in cytology and another 600k EUR was spent on vaccination in 2018/2019. We want decision makers to be informed about proposition of changes to be made in the allocation of the health resources required to implement an optimal (cost/effective) prevention program. Thus we examine: (1) a single year cohort vaccination scenario to test its conditional cost-effectiveness (possible sensitivity to sexual partner acquisition rates and country economic growth) as well as; (2) cytology change from Romanowski to Pap (Papanicolau) smears, would not necessary be cost-efficient in low resource settings.

Epidemiology and fact sheets

Human papillomavirus, or HPV, is a sexually transmittable virus infection, which is not only the main, but also a necessary risk factor for developing cervical cancer $[6,2012]$. The time between getting infected by HPV and developing a cancer can be twenty years or more, therefore a dynamic model of human behaviour would be very useful, so that simulations can be made and different scenarios compared. We observe both behavioural change (sexual partner number increases) and demographical change (population ageing) [7, LUPUSOR, A. et al., 2017]. Among the oncogenic HPVs, the most severe one is type 16, present in about half of all cervical cancer cases. We model one HPV strain (16) and imitate multi-strains environment. Recent studies have shown that the main safety precaution with respect to cervical cancer is going to be a combination of vaccination and screening - since only types of specific vaccines (as for type 16 and 18 in our study) are available and there are as many as 15 oncogenic high risk HPVs not covered by vaccine used in Moldova.

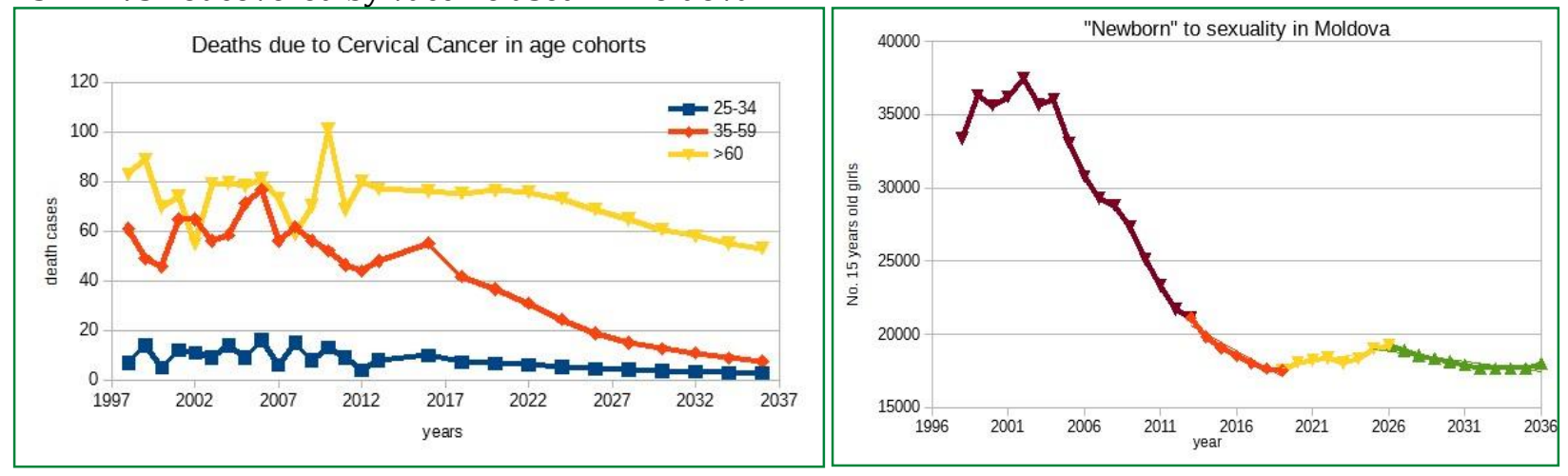

Figure 1. Selected demographical historical data till 2016 and projection (averaged) till 2036. Cervical cancer death cases in age cohorts \{left\}. Number of 15 years old girls entering sexual maturity age \{right\}

Source: Author's calculations based on the Institute of Oncology and Statistics Moldova data.

The Republic of Moldova is one of Europe's poorest nations (whenever we use statistics of Moldova, we mean the Dniester right bank only). Total yearly expenditure on health amounts is limited to just 150 EUR [Fig. 2] per capita (in comparison, the Australian intervention in HPV costs are 8 times higher than the Moldovan one and at the same time consume 5 times less available resources) and reliable data on cervical cancer is missing. Some official statements are untrustable due to a well-known corruption mechanism of reporting "virtual" patients [8, JARYNOWSKI, A., 2015]. The economic situation over the past 2 decades has not allowed for the health systems development [9, SKARPHEDINSDOTTIR, M. et al., 2014]. Till now some statistics differ significantly dependently of data source. Moreover, public health system in Moldova had no capacity to couple with official screening program till 2017 (women $>20 \mathrm{y}$. 0 . every 2 years), where more than 700k test should be done yearly (in 2014 there were around 200k unique cytologies and many sites were already overloaded). Demographically, Republic of Moldova had (in years 1998-2014) a population of 1.4-1.6 million women ages 15 years and older who are at risk of developing cervical cancer. Sexual active woman cohort (age 15-64) was in range 1.25-1.35 millions [10, 2014]. We observe both behavioural change (sexual partner increase) and demographical change (population ageing, but still very young), which both corresponding to second demographic transition since Soviet 
Union collapse. Last 10 years estimates indicate that every year 400-550 (approx. data) women were diagnosed with cervical cancer and 145-220 (register data) died from the disease [11, 2019]. Estimated societal cost was around 5000 disability-adjusted life years (DALYs) every year (or 3000 QALY qualityadjusted life years) [11, 2019; 12, DAVIES, P. et al., 2017]. Cervical cancer ranks as the 2nd most frequent cancer among women in Republic of Moldova and the 1st most frequent cancer among women between 15 and 44 years of age with the share of $39 \%$ of all kind of working age woman cancer cases [12, DAVIES, P. et al., 2017]. The incidence of cervical cancer, had increased from 2005 to 2009. Data on the HPV burden is not available, but generalizing old studies with data from other southeastern European countries, 15$20 \%$ of women in the general population have HPV and $80-90 \%$ had it in their live [13, ROTTGER, J. et al., 2017]. Prevalence of the most oncogenic HPV-16/18 strains is estimated on 25\%. Spatial consideration should be included, while urban/rural sexual behaviour and access to health services differ significantly.

Moldova introduced HPV vaccines in selected subpopulation in 2016 and full coverage of $10 \mathrm{y}$. 0. girls with support from Gavi in 2018 only [Fig. 4]. First national wide suboptimal screening program was introduced in 2013 and updated in 2016 to optimal age-range in almost similar schema as we proposed a year before [12, DAVIES, P. et al., 2017]. The majority of cervical cytology was processed by Romanowski staining technique - standard for the former Soviet Union [14, DAVIES, P., VALUTA, D., 2014].

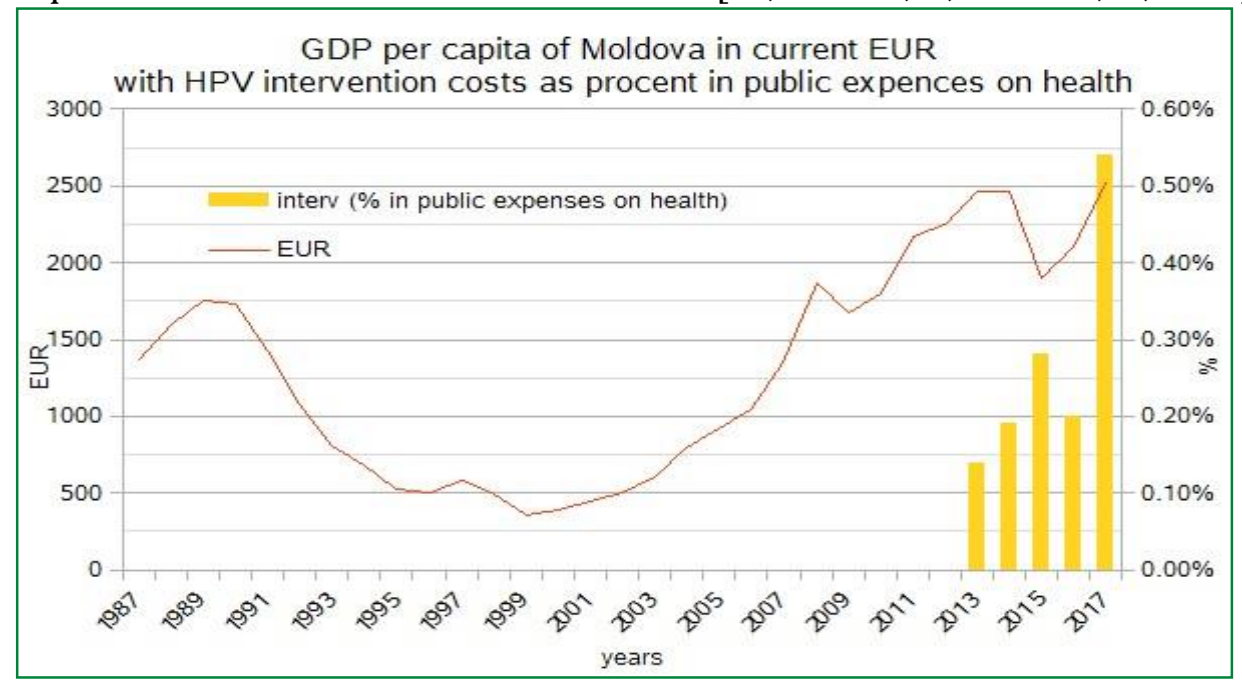

Figure 2. The Moldovan GDP patterns (with unpredictable political and economic situation) \{left $y$ axe $\}$ and HPV intervention costs - the third health expenditure - as \% in total health expenses \{right $y$ axe\}

Source: Author's visualization based on the Statistics Moldova data.

\section{COST-EFFECTIVENESS ANALYSIS}

Let consider more precise monetary and populational effects of intervention used in health economy [15, JARYNOVSKI, A., 2015; 16, 2016]. To do so, we introduce quality-adjusted life-year (QALY) - a measure of disease burden, including both the quality and the quantity of life lived. The QALY is based on the number of years of life and adjusted to health state (where 1 is a perfect health and 0 is death) that would be saved by the intervention. QALY indicates in the best way the benefits of intervention, because it is sensitive to current patient age (literally to current life expectancy). The intervention is highly costeffective if its incremental cost per QALY yearly [17, DAMM et al., 2017] is below GDP per capita of given country ( $\sim 2.5 \mathrm{k}$ EUR for Moldova) or it could be considered as cost-effective if its below $3^{*} \mathrm{GDP}(\sim 7.5 \mathrm{k}$ EUR for Moldova) [18, PHELPS, C., 2016]. In previous papers we showed, that targeted vaccination is costeffective (the incremental QALY between targeted and no vaccination is less than 4k EUR per QALY in 40 years perspective, however practical implementation could be very difficult), while screening the too old and too young woman is not cost-effective (the incremental cost per QALY between national and our scenario was 20k EUR per QALY in 20 years perspective) respectively to Moldova GDP [19, 2014]. It is important to mention, that cervical cancer incidence probably will be decreasing any way in Moldova even with no new additional interventions [20, JARYNOWSKI, A., CERNOV, L., 2018]. Moreover, the 
Moldovan cervical cancer perspective [Fig. 1, 7] looks much better than in other Eastern and Central European countries [21, DOSEKAN, 0., 2010], probably due to recent transition of screening guidelines from opportunistic to organized at the beginning of the XXI-st century [22, DAVIES, P. et al., 2016], and because of a relatively young society with increasing knowledge of STI (sexual transmittable infections).

RESEARCH QUESTIONS. Moldova has modified since 2016 the screening program [14, DAVIES, P., VALUTA, D., 2014] almost the same as we recommended [15, JARYNOVSKI, A., 2015] with small difference in maximum age of screening with 61 instead of 65 which could be an artefact of our age-cohorting schema. Other analytical research approach as PRIME [23, JIT, M. et al., 2014] and OPTIMA [24, GOROSHKO, A. et al., 2015] have provided sufficient cost - effectiveness analysis of standard procedures as screening and vaccination, however their universal tools (both of them were built to be used in many counties) do not fit Moldovan specificity in many details. Big intervention in the period of 2017-2020 with the main objective as reorganization of screening and new vaccination was externally funded in amount of 1.2M EUR [25, 2017]. The Ministry of Health declared the will to continue the vaccination program already for years 2019-2025 [26, 2017], but we are not sure about the real financing of this project (money in amount of 400k EUR are secured for 2019 only [25, 2017]). There is also a strong disbelieve in the Moldovan society about vaccinations safety issues $[27,2019]$ with a strong anti-vaccination political fuel $[28,2018]$. There is still an open question about the cost effectiveness of point (single cohort) vaccinations, because vaccinating single cohort could have no satisfactory effects for the whole population [29, QIAO, M. et al., 2013]. The real scenarios assuming vaccinating 10 y. o. girls in 2018 was not implemented by us, because the first effects would be visible too late for simulation time span. We verify instead a single year vaccination of $14 \mathrm{y}$. o. girls in 2018, so we can keep projection of costs, demographics and epidemiology for the next 20 years only. Quadrivalent vaccine (targeting HPV oncogenic strains 16, 18 , and also non-oncogenic stains 9 and 11 which cause genital warts) is used in 2018, so we introduced additionally to previous studies, effects on genital warts (cost of curing and QALY losses). Increase in cytology cost was also updated due to the change from Romanowski to Pap smear. Vaccination in a single action of a single cohort has not yet been considered from health economic perspective for Moldova. The Moldova case cost-effectiveness analysis is also important to be disseminated worldwide [30, EKWUNIFE, O.I. et al., 2017], due to similar externally founded projects in other Low and Middle Income countries (e.g. GAVI- the Vaccine Alliance).

Research question 1: Testing possible impact of the new 'single' 2018 year project funded mostly by external sources - vaccines for cohort of girls born in $2007 \sim 600 \mathrm{k}$ EUR (400k EUR is a financial cost for program continuation in 2019 with GAVI substitution):

- Estimating incremental costs of adding HPV vaccine in single 2018 to the existing immunization program (reasonable assumption that Moldova will not continue full coverage vaccinating because of lack of resources);

- comparing scenarios of "single year vaccination" in full coverage in 2018 against vaccination of the same amount of girls in the same age but in a 5 year time span (20\% of each cohort each year).

Research question 2: Testing the best budget possibilities according to national screening guidelines since 2018 (Romanowski ->Pap cytology change [31, REBAR, A. et al., 1982]) with capacity building [32, REGAN, D., DONOVAN, B., 2016] cost of 800k EUR (also funded mostly by external sources):

1. Comparing scenarios of various procedure costs per unit (pessimistic - with Romanian price in long term, moderate with Russian price $[33,2019]$ in long term, and optimistic - no significant change).

\section{MODEL AND METHODOLOGY AND ADJUSTING REALISTIC SCENARIOS}

According to provided information, a model for Moldova was proposed. It is a set of deterministic differential equations (implemented in Vensim). Stochasticity [34, GEFFEN, N., SCHOLZ, S., 2017] was introduced in sexual partner matching schema. The model has aggregated the most important path of infection (heterosexual contacts only), cancer development and prevention scenarios (more than 100 equations and 200 parameters). Demographical dataset from comes from "Population and demographic processes" Statistical databank of National Bureau of Statistics [10, 2014; 35, 2017]. HPV dynamics (transmission dynamics via sexual contacts) associated also with the occurrence of cervical cancer (cancer development) was inspired by Polish model implementation [36, JARYNOWSKI, A., 
SERAFIMOVIC, A., 2014]. Mathematical formulation of HPV related issues have been already carefully analysed, because its epidemiology has been widely described and modelled in recent years [32, REGAN, D., DONOVAN, B., 2016; 37, CANFEL, K. et al., 2019]. We have prepared the costbenefit and costeffectiveness analysis for various vaccination strategies, various screening programs with control over other preventive programs (using condoms/sexual education) for Moldova, based on its own demography (sex/age structure with aging and birth/death processes) $[35,2017]$ and sexual behaviour of heterosexual part of population only [38, RAHMAN, Q., 2003]. Population is divided in subcategories (both man and woman) which are aging, transmitting infection and developing cancer, where newborn to sexuality means reaching 15 y. o. [Fig. 3].

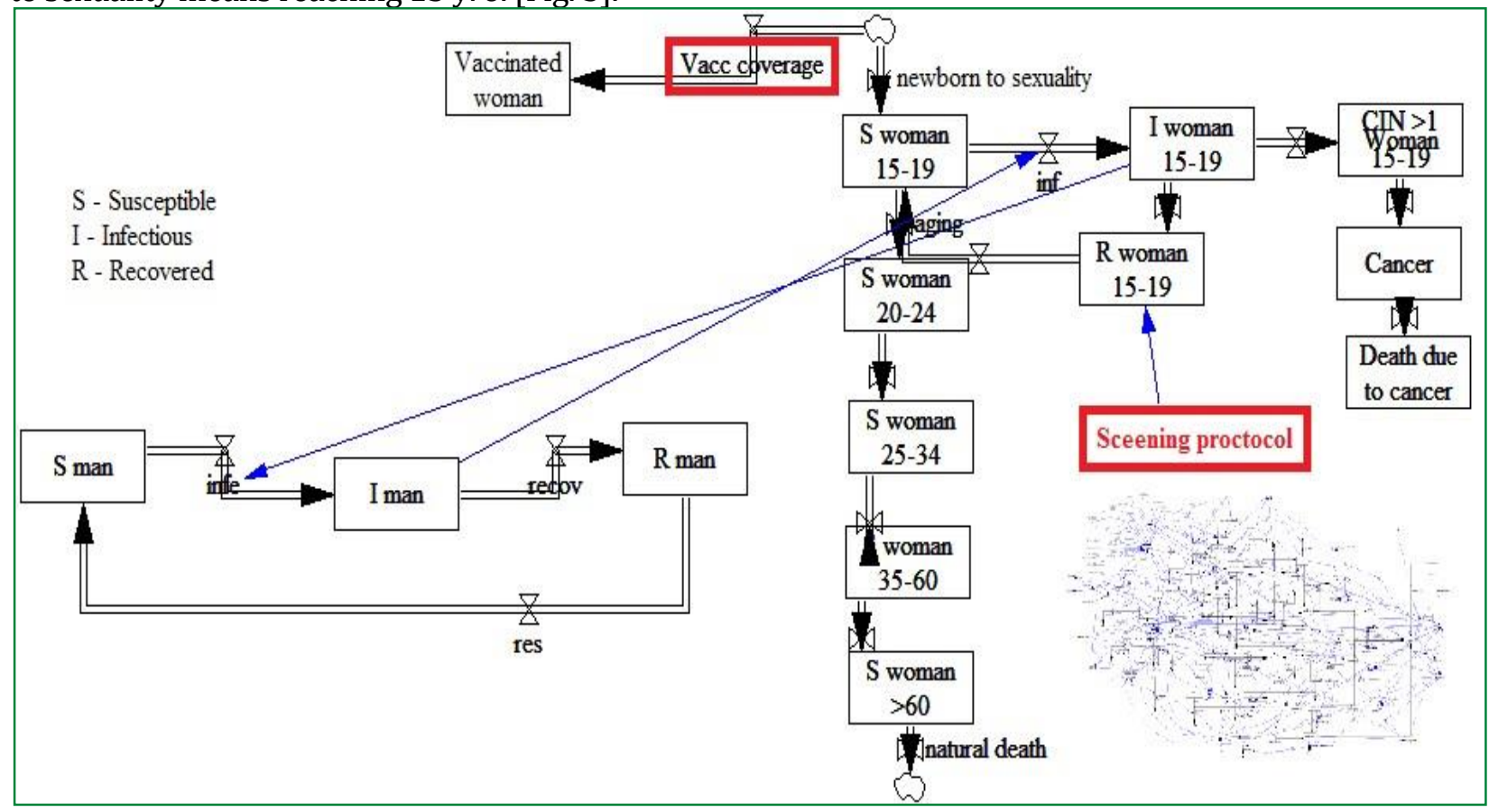

Figure 3. Simplified model methodology with main tunable variables screening protocol and vaccination strategies). Full model in left bottom corner -visualization of this very complicated model in Vensim (Exportable version can be obtained from Github: https://github.com/ajarynowski/HPV_Moldova - free Vensim reader is available from www.vensim.com)

Source: Author's own model available on Github.

We used data since 1998 (2002) till 2014 (2017) to adjust model parameters and we project till our result around 2035 (2038). We use mathematical [39, GRABOWSKI, A., ROSINSKA, M., 2012] and sociological concepts [21, DOSEKAN, 0., 2010] within complex system methodology. Mathematical modelling of infectious diseases transmitted by sexual contacts (as HPV) is increasingly being used to determine the impact of possible interventions (there are dozens of such studies in literature [36, JARYNOWSKI, A., SERAFIMOVIC, A., 2014; 40, ELBASHA, E.H. et al., 2007; 41, RYDING, J., 2008]. We have used probability of infection per a new partner as a main transmission driver. The shape of sexual partner distribution [42, LILJEROS, F. et al., 2000] was followed from Finish study [43, BARNABAS, P. et al., 2006] and adjusted by scaling to obtain mean partners number in Moldova. The most unknown demographical parameter is the increase in partner numbers [44, 2018]. That increase of partner' acquisition was introduced as a modifiable variable and tested for few scenarios $[44,2018]$. In our model woman are stratified in 5 years cohorts (stocks) starting form $15 \mathrm{y}$. o. Effective screening intervals (average interval between smears) were previously implemented as a variable (more important from cost/effectiveness analysis) describing healthcare system capacity [20, JARYNOWSKI, A., CERNOV, L., 2018]. Change of screening procedures from opportunistic to regular is also represented in effective screening frequencies [14, DAVIES, P., VALUTA, D., 2014] and costs [fig. 4]. Condom use was also tunable variable, while sexual education significantly increased in recent few years [45, 2016; 46, JARYNOWSKI, A., 2015]. Standard 
model is better described in extended version of previous report [46, JARYNOWSKI, A., 2015], and new functionalities are mentioned directly in this paper. The model and its parametrization in Vensim environment is publicly available: http://github.com/ajarynowski/HPV_Moldova.

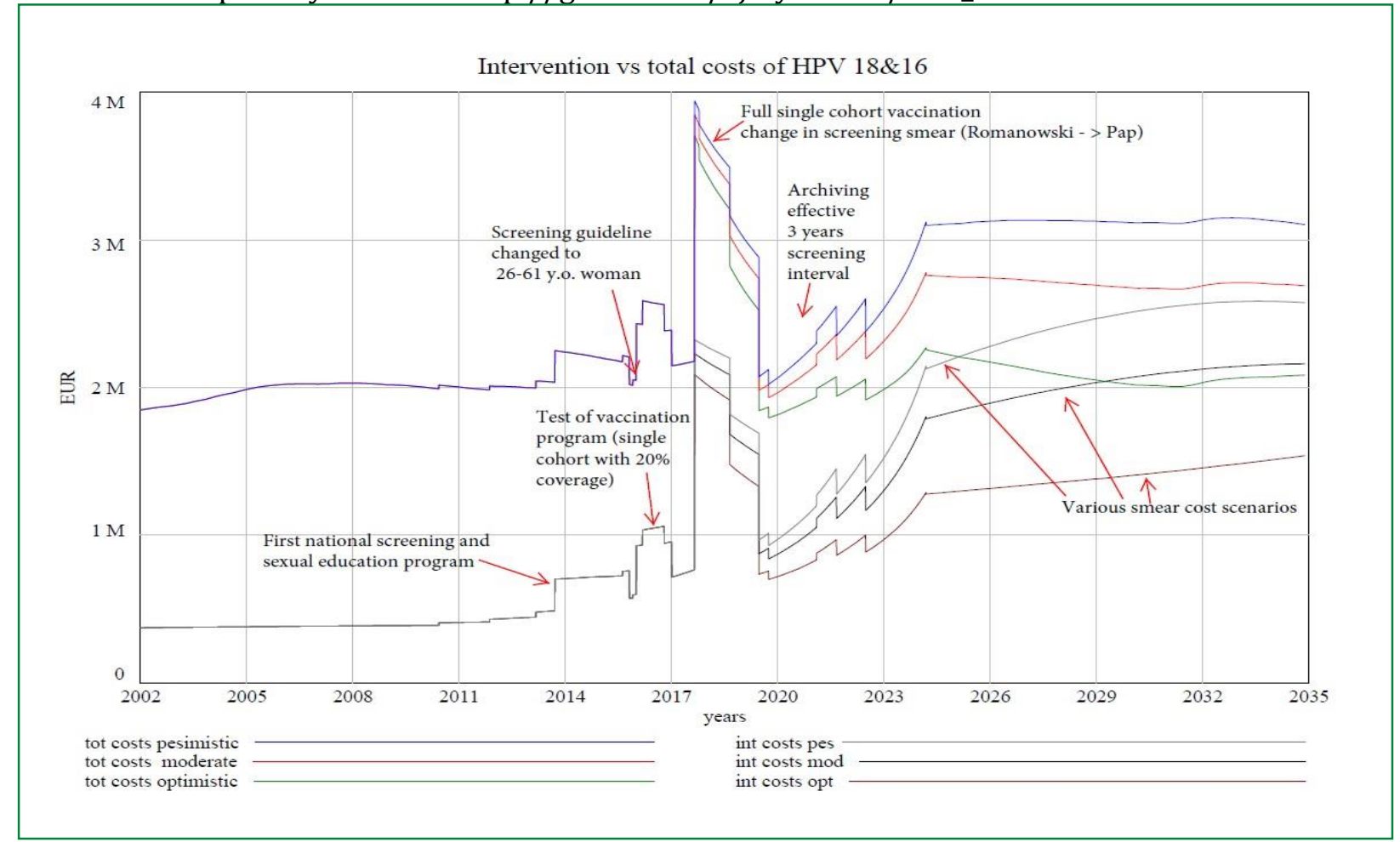

Figure 4. Simplified Moldovan history of pathogenic HPV strains costs. Intervention (int) costs (sexual education, vaccination, screening) and Total (tot) costs (intervention costs with mainly cervical cancer treatment as well as other treatment costs of pre-cancer Source: Authors own projections. abnormalities, anus cancer, genital warts)

In our calculations we provide economic costs (total expenses), which differ from financial costs (Moldova Government expenses), because of the importance of foreign aids. Intervention costs (sexual education, vaccination, screening) till 2017 counts as $1 / 4$ of treatment costs. In big investments in Moldovan Cervical Cancer Program in years 2017-2020 intervention costs (funded by GAVI, World Bank, United Nations Population Fund - UNFPA, Swiss Contribution - SDC, European Union - UE, etc.) exceeds treatment costs.

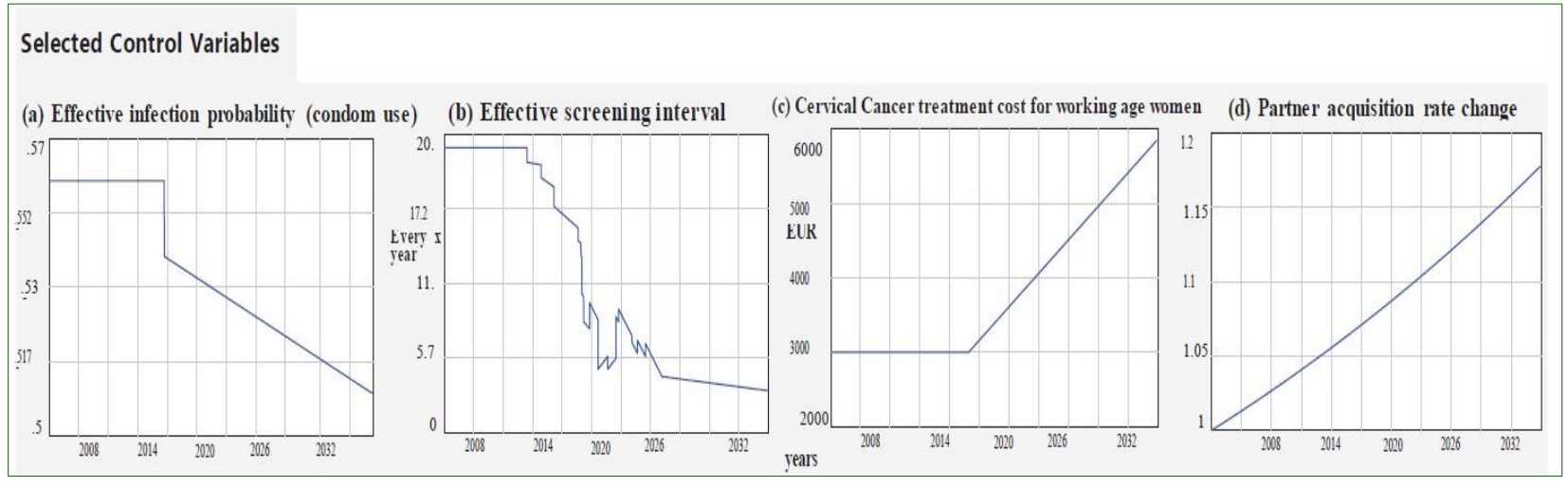

Figure 5. Selected control variables in model projection ((a) effective infection probability - condom use, (b) effective screening interval in years, (c) cancer treatment cost in EUR,

(d) sexual partner change rate as multiplicator)

Source: Author's own assumptions. 


\section{RESULTS - RESEARCH QUESTION 1) ROMANOWSKI->PAP SMEARS}

There is only a little difference in epidemiology between Romanowski and Pap smear in specificity [Tab. 1]. Lower specificity of Romanowski can be corrected by repeated Pap test (mainly with borderline results) [47, DAVIS, P. et al. 2016].

However, there is a substantial difference in cost procedure and Pap smear could be $30 \%$ to $90 \%$ more expensive for a single procedure [Fig. 6], but the same time number of procedures would decreased by around $10 \%$, because there is no need for repetition any more.

\section{Characteristics of smears. False Positive rate change-> test repetition} (up to $10 \%$ due to unclear result)

\begin{tabular}{|l|c|c|c|}
\hline Cytology & $\begin{array}{c}\text { Sensitivity for } \\
\text { morphological } \\
\text { abnormalities in HPV } \\
\text { positive stage without mid- } \\
\text { and high-grade dysplasia }\end{array}$ & $\begin{array}{c}\text { Sensitivity for } \\
\text { morphological } \\
\text { abnormalities in pre- } \\
\text { cancer stage with } \\
\text { mid- and high-grade } \\
\text { dysplasia (CIN }>\text { I) }\end{array}$ & $\begin{array}{c}\text { Specificity for } \\
\text { morphological } \\
\text { abnormalities in HPV } \\
\text { positive or pre- cancer } \\
\text { stage }\end{array}$ \\
\hline Pap & $60 \%$ & $90 \%$ & $98 \%$ \\
\hline Romanowski & $60 \%$ & $90 \%$ & $\sim 90 \%$ \\
\hline
\end{tabular}

Source: Author`s own estimates based on [48, 2013].

While the rising trend in innovative medical technologies (as Pap smear in this case), the chances for efficiency gains and costs reductions are usually large. However, new technology-enabled models of healthcare delivery are not always cost-effective. Capacity building (transitional) costs in this case were covered by foreign sponsors, but equipment amortization and staff cost should be sustain by Moldovan themselves. We try to anticipate costs per procedure in next 20 years [Fig. 6]. We choose target level of future price from Romania (as a pessimistic scenario), Russia (moderated scenario) and current price with most likely interest rate (as optimistic scenario). We assume 15 years amortization period for equipment (characteristic convey curve shape) [Fig. 6]. Reader must be aware, that currently PCR test together with liquid base Pap smear is a standard in developed countries, however machine learning development in image processing for low-cost diagnosis [49, GALLAY, C. et al., 2017] could change whole landscape in next years.

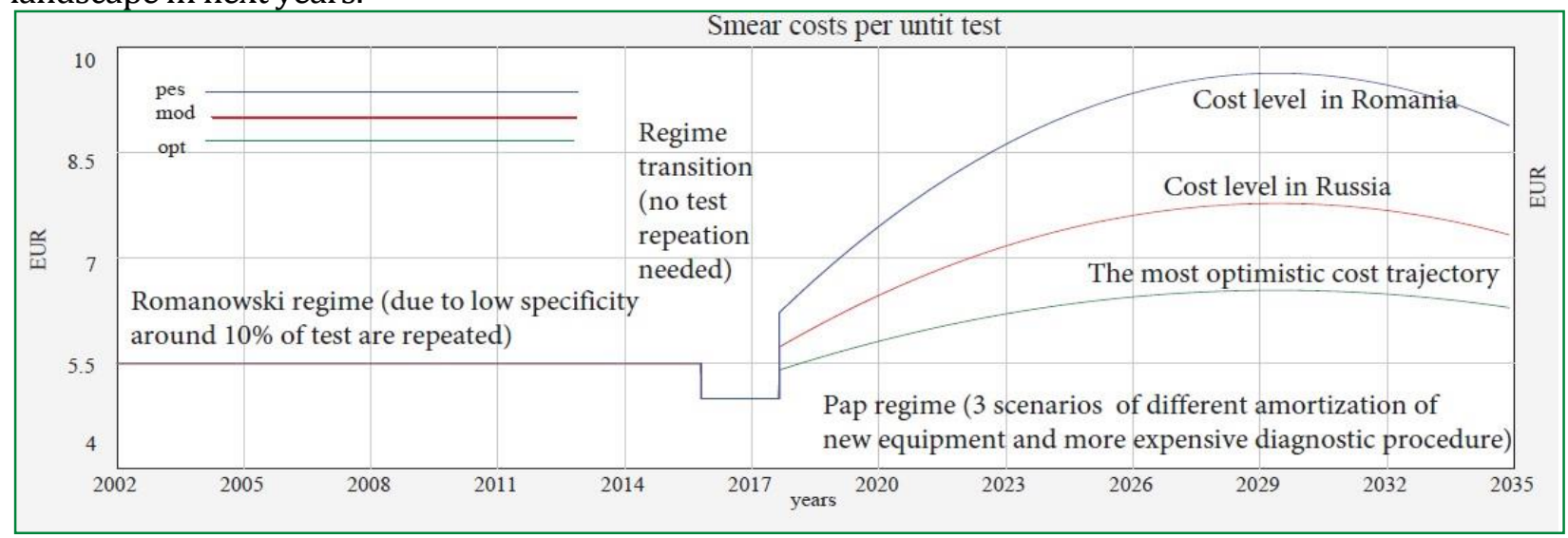

Figure 6. Smear cost per unit for pessimistic (pes), moderate (mode) and optimistic (opt) scenarios. In transitional time window (2017-2018) cost per procedure (operational cost) deceased, because capacity building costs $\sim 800 \mathrm{k}$ EUR (training old and hiring new staff, laboratory equipment etc.) includes partially operational costs

Source: Author's own assumptions.

Let's consider baseline scenario, for which Moldova will stay in Romanowski regime. If we assume that drop-out rate at the level of $20 \%$ in repetition tests, there will be around 12 QALY/yearly loses more that in Pap scenario in 20 years projection. Around 10 cancer cases and 4 deaths could be averted with 
the transition to Pap in 20 years perspective. However, cost comparison is more difficult due to potential instability of Pap procedure price [Fig. 6], so incremental cost-effectiveness vary from 0 in optimistic to 50k incremental EUR/QALY in pessimistic scenario.

Results - Research Question 2) 'Single' cohort vaccination

First of all, we compare the single cohort vaccination against no widespread vaccination at all. Vaccination is both cost-beneficial (total cost reduction balance intervention cost around year 2040) and cost-efficient (with incremental impact in 20 years perspective on the level of 2200 EUR/QALY) [Fig. 7].

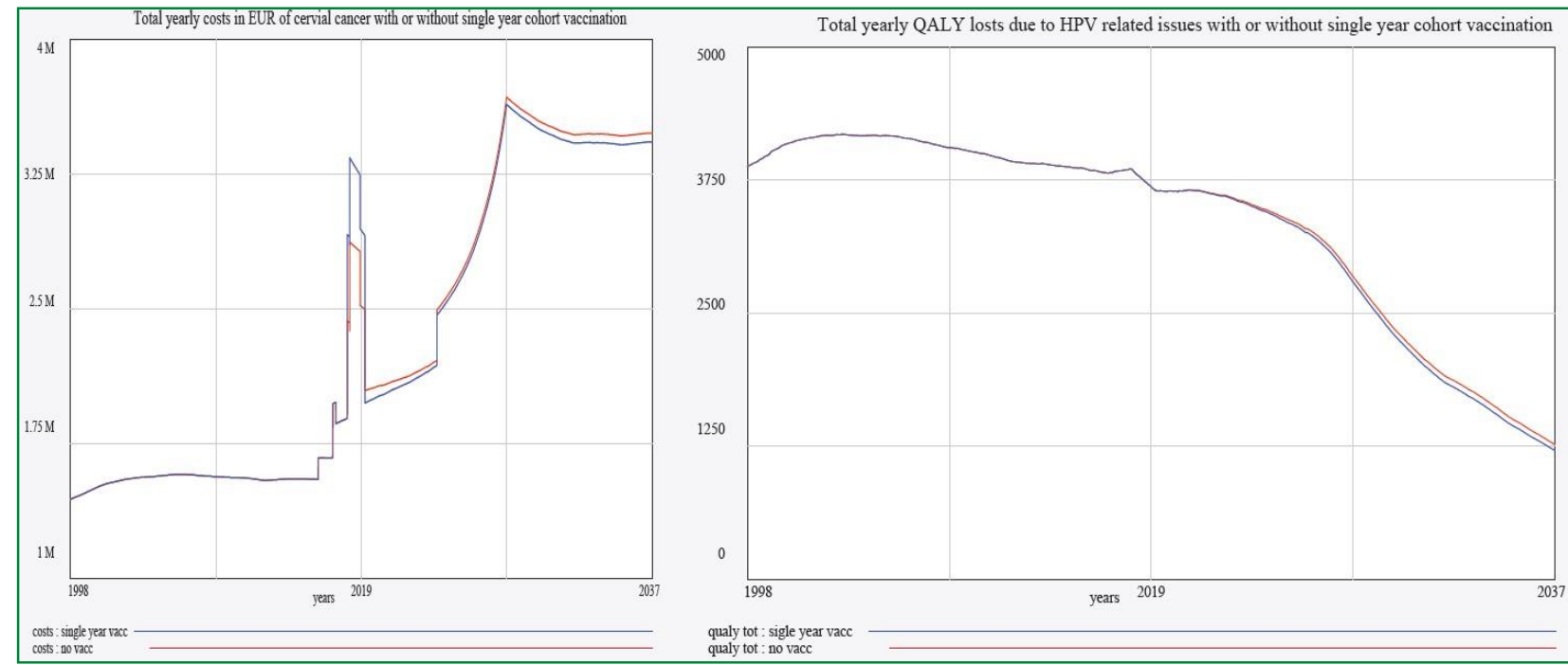

Figure 7. Comparison of total costs of HPV related issued (interventions, genital warts and cancers) \{left\} and QALY losses \{right\} with and without vaccination in 2018

Source: Author's own projections.

Thus we examine such a single year vaccination scenario to show its conditional costeffectiveness in comparison with 5-year cohort vaccination scenario. We assume that 15120 girls has been vaccinated for both single year cohort and 5-year cohort scenarios two years after and before 2018 [Fig. 8].

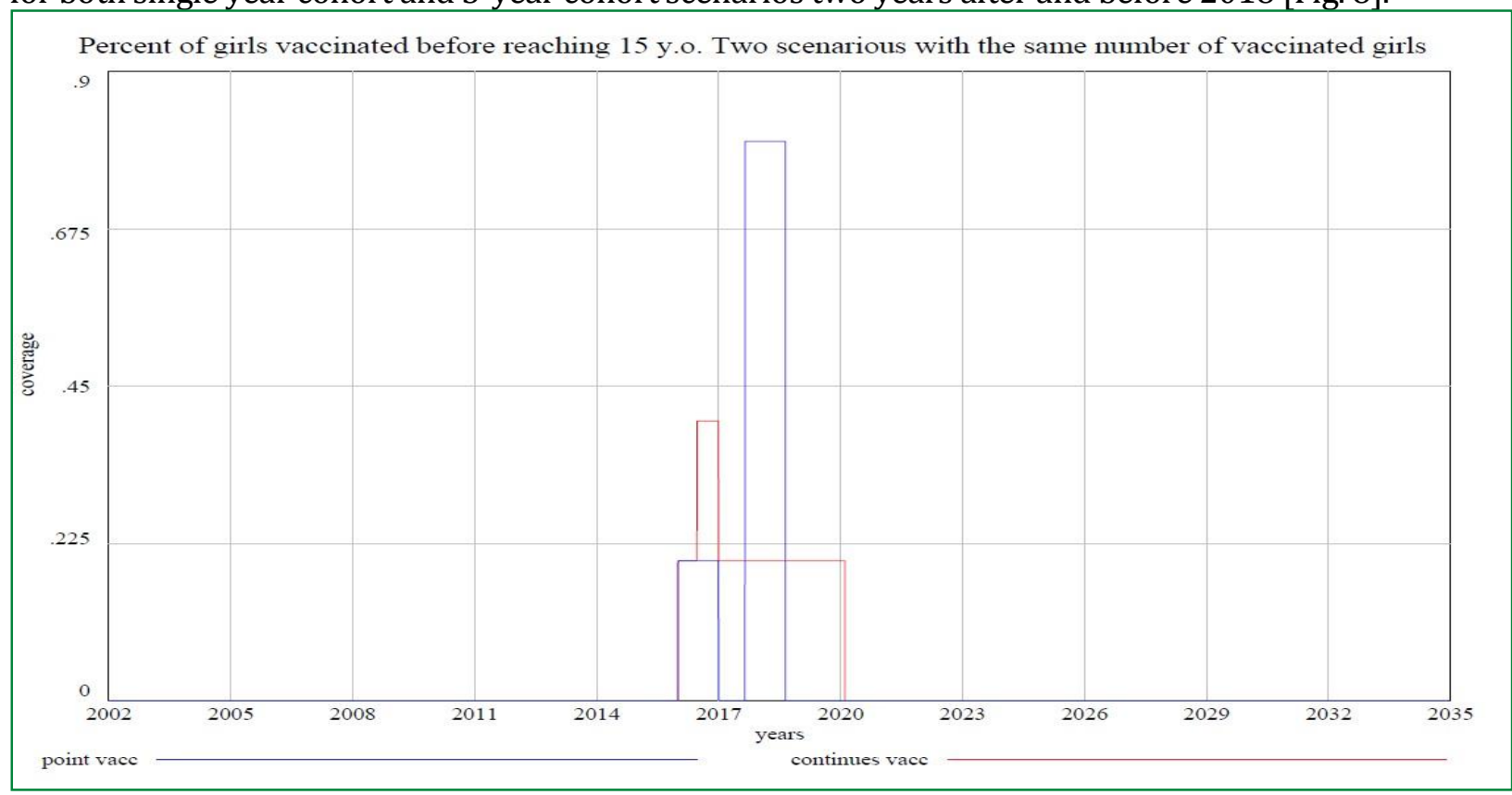

Figure 8. Vaccination coverage of 15120 girls in both scenarios single year/5-years cohort Source: Author`s own assumptions. 
We found out that difference in number of HPV infections is $\sim 610$ and difference in QALY saved is $\sim 80$ in favour of single year against 5 -years cohort vaccination in next 20 years.

Comparing a single year with 5-years cohort in young woman (15-19 y. o.) we observed the increase of infection number between a single year and 5-years cohort scenarios in first 1-2 years (because we started 2 years earlier vaccination in 5-years scenario), then around 2019-2022 there is a significant reduction in infections, and there is no long term difference between scenarios (due to aging moving vaccinated girls to older cohorts). In males, first difference between single year and 5-years cohort scenarios appears in next 5-10 years (when vaccinated women enter their early 20 th years old - the most sexually active period of their life $[33,2019])$.

CONCLUSIONS. RECOMMENDATIONS AND LIMITATION

The optimal preventive guidelines for cervical cancer are known [32, REGAN, D., DONOVAN, B., 2016]: cervical screening practice, widespread vaccination and sexual education. However, interventions with the highest impact and lowest price should be prioritized [50, KASPRZYK, R. et al., 2010]. In addition, Moldova - lower middle income country - straggles with challenging demographic processes, like the ageing of the society [51, GAGAUZ, O. et al., 2016; 52, GAGAUZ, O, PAHOMII, I., 2017] and the increase of sexual activity [53, HRUSCIOV, E., 2017] combined with the unstable economic situation [54, PISCHINA, T., 2016]. We suggest (according to our simulation) that the official preventive program for cervical cancer in Moldova is optimal in terms of costs and medical efficiency in vaccination schema and suboptimal in screening protocols (optimal in medical efficiency only). We present a simplified representation of the system with around 200 static parameters and additional 20 time dependent control parameters variables (such as condom use, effective screening interval, partner's acquisition rate, cancer treatment cost [Fig. 5], etc.). We consider different scenarios varying the tunable variables (vaccination coverage type [Fig. 8] and smear cost [Fig. 6]). Exact parametrization of the model used for this paper can be found in repository (github). However, reader must be aware, that presented model and parametrization has been chosen according to a heuristic methodology [55, JARYNOWSKI, A. et al., 2018]. Although we explored other models and parameters configuration, we cannot claim, that our model is the only and the best one for targeting research question 1 (vaccination) and 2 (screening). On the other hand, the main advantage of our model in comparison with well-established modelling tools already applied to Moldova (developed by WHO - PRIME [23, JIT, M. et al., 2014] and sponsored by World Bank OPTIMA []) is its flexibility. In our model, we can test different scenarios (as cohort vaccination, and smear price dynamics), which is not possible or feasible in PRIME and OPTIMA, and our findings should be understood as complementary results only.

The idea of transition from Romanowski to Pap smear cytology (research question 1), is unquestionable (due to higher specificity of the last). However, further maintenance and higher procedure costs [Fig. 6] might exceed treatment costs, implying unacceptable share in whole national limited resources dedicated for public health for intervention costs [Fig. 2, 4]. We found an interesting paradox, that transition to more technologically advanced health system (changing from Romanowski to Pap smears), would not necessary be cost-efficient (incremental cost-effectiveness from 0 to $50 \mathrm{k}$ EUR/QALY) in such low resource settings as in Moldova and unstable GDP growth perspective. Reader must be aware, that we simplified difference between Romanowski and Pap smears in procedure cost (trained staff and lab equipment amortization) and specificity (test repetition in Romanowski method) issue only, even both methods have many variants [57, 2003].

We reopen discussion about vaccination guidelines in low-income countries (as Moldova), where cost of widespread action could be too high for local governments (research question 2). Vaccination could be both cost-beneficial (total costs reduction balance intervention costs before 2037) and costeffective (with incremental impact in 20 years on the level of 2200 EUR/QALY). Moreover, the single cohort (point) vaccination (as it was introduced in Moldova) exceeds the 5 years cohort by approximately 610 less infections and approximately 80 less QALY lost in 20 years' time horizon. The possible explanation of this nonintuitive behaviour might be because HPV in Moldova is rather close to epidemic reproduction threshold rate [55, JARYNOWSKI, A. et al., 2018], still small change of model parameters and initial conditions could cause strong effect in epidemiology. Main effect of intervention is probably via men, which avoid infection (mainly around year 2025 - the peak of sexual activity of vaccinated girls) and will not infect other women. The decrease in infection numbers (and QALY loses in consequence) 
resulting from the 'single' teenage cohort HPV vaccination in 2018 might provide protective effects in heterosexual men through 'local' herd immunity [56, DONOVAN, B. et al., 2011]. This can have an effect probably while changing partners in Moldova is still not as common as in other countries [57, 2003; 58, ROSTAS, I. ș.a., 2014]. However, change in initial conditions and parameter values could diminish positive effect (e.g. higher partner's acquisition rate). Another limitation is System Dynamic approach [55, JARYNOWSKI, A. et al., 2018], so few features as real sexual patterns matching were not implemented. There is no distinguish of rural and urban population or any spatial resolution [59, BELIK, V. et al., 2011] in the model, which have impact both on partner's acquisition and vaccine/screening uptake. Phenomenon of single cohort vaccination cost-effectiveness must be investigated more carefully in different methodology (as ABM Agent Based Modelling [55, JARYNOWSKI, A. et al., 2018]) from presented one (System Dynamics) to understand role of men in immunisation efficacy for example. Moreover, no proper sensitivity analysis could be readily performed using the current methodology (limitation of Vensim software) in presented study, even we have found dependence on changing condition, so only through ABM - obtained results could be generalized. Another limitation is time horizon for 20 years, which is already too far for price/demography/technological assumptions and too short to even test efficiency of vaccination of cohort of $10 \mathrm{y}$. o. girls (so we could test vaccinating $14 \mathrm{y}$. o. instead). We have used aggregated age cohorting [60, ANDERSON, R.M., MAY, R.M., 1992] with 5 years window, which on the one hand side is a popular approach [46, JARYNOWSKI, A., 2015; HORN, J. et al., 2013] - on the second hand it has significant limitations, so year by year analysis could be more proper for single year cohort vaccination schema.

We recommend continuation of vaccination which is both financial (with GAVI substitute) and economic cost-effective according to our model. In terms of screening technology transition: there is no way to go back, however screening costs have to be periodically monitored and national guidelines could be revisited (if necessary) according to economic situation in Republic of Moldova.

\section{Acknowledgment}

AJ would like to thank to Liana Cernov, Florentin Paladi, Ghennadii Gubceac from the Moldova State University, Vitaly Belik from the Free University of Berlin, David Regan, Trevor Dougherty and Richard Gray from the Kirby Institute in Sydney as well as the PANTHER project for partial financial support. Codes are publicly available in a repository: https://github.com/ajarynowski/HPV_Moldova.

\section{REFERENCES}

1. Sexually Transmitted Infections in Europe 1990-2010: surveillance report. European Centre for Disease Prevention and Control. Stockholm, 2012, june. [Accesat 03.05.2019]. Disponibil: https://www.ecdc.europa.eu/sites/portal/files/media/en/publications/Publications/201206Sexu ally-Transmitted-Infections-Europe-2010.pdf

2. WORLD HEALTH ORGANIZATION. Sexual and reproductive health. 2012. [Accesat 11.06.2019].

Disponibil: http://www.euro.who.int/en/health-topics/Life-stages/sexual-and-

reproductivehealth/sexual-and-reproductive-health

3. MOCANU, V., DUMBRAVENAU A. Historical And Socio-Political Aspects Of The Stratification In The Republic Of Moldova'S Society. In: Economie şi Sociologie = Economy and Sociology. 2013, nr. 2, pp. 190-192. ISSN 1857-4130.

4. ARBYN, M. et al. Trends of cervical cancer mortality in the member states of the European Union. In: European journal of cancer. 2009, vol. 45 (15), pp. 2640-2648. ISSN 0959-8049.

5. BRISSON, M. et al. Population-level impact, herd immunity, and elimination after human papillomavirus vaccination: a systematic review and meta-analysis of predictions from transmission-dynamic models. In: The Lancet Public Health. 2016, vol. 1 (1), pp. 8-17. ISSN 24682667.

6. WORLD HEALTH ORGANIZATION. Sexually transmitted infections. 2012. [Accesat 17.08.2019]. Disponibil: http://data.euro.who.int/cisid/?TabID=508968 
7. LUPUSSOR; A. ș.a. Demography matters: How population dynamics impacts the economy of the Republic of Moldova? An analytical report on national Transfer Accounts for the Republic of Moldova. Chisinau, 2017, september 29.54 p.

8. JARYNOWSKI, A. Collapse of cooperation and corruption in a mathematical model within game theory including Moldovan case study (Homo Sociologicus vs Homo Economicus). In: Aspecte ale dezvoltării potențialului economico-managerial în contextul asigurării securității naționale: conferința științifico-internațională, 6-7 iulie 2015. Bălți, 2015, pp. 98-103. ISBN 978-9975-13235-0.

9. SKARPHEDINSDOTTIR, M. et al. Better non-communicable disease outcomes: challenges and opportunities for health systems: Republic of Moldova country assessment. World Health Organization. Health Policy Paper Series. 2014, no. 14. [Accesat 03.05.2019]. Disponibil: http://www.euro.who.int/_data/assets/pdf_file/0008/255464/BetterNCDoutcomesChallenge sOpportunitiesHealthSystemsMoldovaCountryAssessmentEng.pdf?ua=1

10. National Bureau of Statistics of the Republic of Moldova. 2014. [Accesat 23.06.2019]. Disponibil: https://statistica.gov.md/index.php?l=en

11. ICO HPV. Human Papillomavirus and Related Cancers: Republic of Moldova. [Accesat 11.05.2019]. Disponibil: https://hpvcentre.net/statistics/reports/MDA.pdf

12. DAVIES, P. et al. Implementing an organised cervical screening programme in the Republic of Moldova-stakeholder identification and engagement. In: Cancer epidemiology. 2017, vol. 50, pp. 272277. ISSN 1877-7821.

13. ROTTGER, J. et al. Economic evaluation of HPV vaccine introduction in the Republic of Moldova. 2017, march. [Accesat 23.05.2019]. Disponibil: https://www.mig.tu-berlin.de/fileadmin/ a38331600/2017.lectures/Minsk_20170315.wq_Moldova_costeffectiveness.pdf

14. DAVIES, P., VALUTA, D. Capacity Assessment and Recommendations for a National Cervical Cancer Screening Program in the Republic of Moldova. United Nations. Chisinau, 2014, february. [Accesat 14.06.2019]. Disponibil: https://moldova.unfpa.org/sites/default/files/pubpdf/assessmentrecommendations_cervical\%20 cancer\%20screening\%20moldova\%202014_en.pdf

15. JARYNOWSKI, A. Optimal'noe strategii profilaktiki raka šejki matki - model' dlâ Moldovy. V: Naučnyj dialog. 2015, № 1.

16. Republic of Moldova progress report on hiv. United Nations Joint Programme on Hiv/Aids. Chisinau, 2016. $33 \mathrm{p}$.

17. DAMM, O., HORN, J. et al. Cost-effectiveness of human papillomavirus vaccination in Germany. In: Cost Effectiveness and Resource Allocation. 2017, vol. 15 (1). ISSN 1478-7547. [Accesat 15.05.2019]. Disponibil: https://resourceallocation.biomedcentral.com/track/pdf/10.1186/s12962-017-0080-9

18. PHELPS, C. Health economics. London: Taylor and Francis, 2016. 551 p. ISBN 9781315510682.

19. WORLD HEALTH ORGANIZATION. Choosing interventions that are cost-effective. Geneva, 2014. [Accesat 03.05.2019]. Disponibil: http://www.who.int/choice/en/ [retrieved 04.10.2019]

20. JARYNOWSKI, A., CERNOV, L. Optimal cervical cancer preventing strategies - model for Moldova. 2018. [Accesat 18.05.2019]. Disponibil:

https://posterng.netkey.at/isid/viewing/index.php?module=viewing_poster\&pi=1415

21. DOSEKAN, O. An overview of the relative risks of different sexual behaviours on HIV transmission. In: Current opinion in HIV and AIDS. 2010, vol. 5 (4), pp. 291-297. ISSN 1746630X.

22. DAVIES, P. et al. Assessment of Cervical Cytology Services in the Republic of Moldova and Recommendations for their Reorganisation to Comply with International Evidence-Based Standards. Chisinau, 2016, december. [Accesat 15.07.2019]. Disponibil:

https://moldova.unfpa.org/sites/default/files/pubpdf/RM\%20Cervical\%20Cytology\%20Assessment\%20\%20Recommendations_eng.pdf

23. JIT, M. et al. Cost-effectiveness of female human papillomavirus vaccination in 179 countries: a PRIME modelling study. In: The Lancet Global health. 2014, vol. 2 (7), pp. 406-414. ISSN 2214109X. 
24. GOROSHKO, A. et al. Optimizing Investments in Moldova's HIV Response. World Bank. Washington DC, 2015. [Accesat 03.05.2019]. Disponibil:

https://openknowledge.worldbank.org/bitstream/handle/10986/25396/109600.pdf?sequenc $\mathrm{e}=5$ \&isAllowed $=\mathrm{y}$

25. SDC. Cervical Cancer Prevention Project in the Republic of Moldova. 2017, november 6. 2 p. [Accesat 03.05.2019]. Disponibil: https://moldova.unfpa.org/en/publications/cervical-cancerpreventionproject-republic-moldova

26. V Moldove 15000 devoček smogut polučit' besplatno vakcinu ot virusa papillomy čeloveka. V:

Moj Mir. 2017, aprel'- iûn'. [Accesat 23.05.2019]. Disponibil: http://positivepeople.md/upload/info/lib/uvt_j05med.pdf

27. Assessment of Knowledge, Attitudes and Practices on Cervical Cancer Prevention in the Republic of Moldova - KAP Survey. 2019, february. [Accesat 11.07.2019]. Disponibil:

https://moldova.unfpa.org/en/publications/assessment-knowledge-attitudes-andpracticescervical-cancer-prevention-republic

28. Efecte adverse ale vaccinului anti-HPV. Ce cred japonezii. 2018, 17 aprilie. [Accesat 03.05.2019]. Disponibil: https://sputnik.md/analytics/20180417/18586258/vaccin-gardasil-cervarixefecteadverse-HPV-informare-ce-cred-japonezii.html

29. QIAO, M. et al. Qualitative analysis of the SICR epidemic model with impulsive vaccinations. In: Mathematical Methods in the Applied Sciences. 2013, vol. 36 (6), pp. 695-706. ISSN 1099-1476.

30. EKWUNIFE, O.I. et al. Challenges in cost-effectiveness analysis modelling of HPV vaccines in lowand middle-income countries: A systematic review and practice recommendations. In: Pharmacoeconomics. 2017, vol. 35 (1), pp. 65-82. ISSN 1170-7690; ISSN 1179-2027.

31. REBAR, A., BOON, G., NICOLA, D. Cytologic Comparison of Romanowsky Stains and Papanicolaou-type Stains II. Cytology of Inflammatory and Neoplastic Lesions. In: Veterinary clinical pathology. 1982, vol. 11 (2), pp. 16-25. ISSN 0275-6382; ISSN 1939-165X.

32. REGAN, D., DONOVAN, B. Balancing the cost-benefit equation for cervical cancer prevention: a moving target. In: The Lancet Public Health. 2016, vol. 1 (2). [Accesat 03.05.2019]. Disponibil: https://www.thelancet.com/action/showPdf?pii=S2468-2667\%2816\%2930024-X

33. European Medical Center. [Accesat 03.05.2019]. Disponibil: https://www.emcmos.ru/clinics/klinika-ginekologii-i-onkoginekologii/ginekologiya

34. GEFFEN, N., SCHOLZ, S. Efficient and Effective Pair-Matching Algorithms for Agent-Based Models. In: Journal of Artificial Societies and Social Simulation. 2017, vol. 20 (4). ISSN 14607425. [Accesat 15.10.2019]. Disponibil: http://jasss.soc.surrey.ac.uk/20/4/8.html

35. National Bureau of Statistics of the Republic of Moldova. 2017. [Accesat 15.10.2019]. Disponibil: https://statistica.gov.md/search.php?go=1\&l=en\&q=2017

36. JARYNOWSKI, A., SERAFIMOVIC, A. Studying Possible Outcomes in a Model of Sexually Transmitted Virus (HPV) Causing Cervical Cancer for Poland. In: Advances in Intelligent Systems and Computing. 2014, pp. 129-141. [Accesat 15.10.2019]. Disponibil:

https://link.springer.com/chapter/10.1007/978-3-642-39829-2_12

37. CANFEL, K. et al. HPV-FRAME: A consensus statement and quality framework for modelled evaluations of HPV-related cancer control. In: Papillomavirus Research. 2019, vol. 8, december.

[Accesat 15.10.2019]. Disponibil: https://www.sciencedirect.com/science/article/pii/S2405852119300230?via\%3Dihub

38. RAHMAN, Q. Born gay? The psychobiology of human sexual orientation. In: Personality and Individual Differences. 2003, vol. 34, pp. 1337-1382. ISSN 0191-8869.

39. GRABOWSKI, A., ROSINSKA, M. The relationship between human behavior and the process of epidemic spreading in a real social network. In: Physics of Condensed Matter. 2012, vol. 85 (7).

[Accesat 15.10.2019]. Disponibil: 
https://www.researchgate.net/publication/257866583_The_relationship_between_human_beh avior_and_the_process_of_epidemic_spreading_in_a_real_social_network

40. ELBASHA, E.H. et al. Model for assessing Human Papillomavirus vaccination strategies. In:

Emerging Infectious Diseases. 2007, vol. 13 (1). [Accesat 15.10.2019]. Disponibil:

https://wwwnc.cdc.gov/eid/article/13/1/06-0438_article

41. RYDING, J. Seroepidemiology as basis for design of Human Papillomavirus vaccination program. In: Vaccine. 2008, vol. 26 (41). [Accesat 15.10.2019]. Disponibil: https://www.sciencedirect.com/science/article/pii/S0264410X08009869

42. LILJEROS, F. et al. The web of human sexual contacts. In: Nature. 2000, vol. 411 (6840), pp. 907908. ISSN 0028-0836; ISSN 1476-4687.

43. BARNABAS, P. et al. Epidemiology of HPV 16 and cervical cancer in Finland and the potential impact of vaccination: Mathematical modelling analyses. In: PLoS Med 3. 2006, vol. 5. [Accesat 15.10.2019]. Disponibil: https://journals.plos.org/plosmedicine/article?id=10.1371/journal.pmed.0030138

44. OECD. Youth Well-being Policy Review of Moldova. 2018. [Accesat 15.10.2019]. Disponibil: https://www.oecd.org/countries/moldova/Youth_Well-being_Policy_Review_Moldova.pdf

45. UNAIDS. Republic of Moldova progress report on HIV/AIDS. Chisinau, 2016. 33 p.

46. JARYNOWSKI, A. HPV and cervical cancer in Moldova, epidemiological model with intervention's cost vs benefit and effectiveness analysis. 2015. [Accesat 11.08.2019]. Disponibil: https://arxiv.org/ftp/arxiv/papers/1504/1504.05383.pdf

47. DAVIES, P. et al. Assessment of Cervical Cytology Services in the Republic of Moldova and Recommendations for their Reorganisation to Comply with International Evidence-Based Standards. Chisinau, 2016, december. [Accesat 11.08.2019]. Disponibil: https://moldova.unfpa.org/sites/default/files/pubpdf/RM\%20Cervical\%20Cytology\%20Assessment\%20\%20Recommendations_eng.pdf

48. Cervical Cancer Screening and Treatment in Low-Resource Settings: Practical Experience From PATH. PATH. 2013. [Accesat 23.08.2019]. Disponibil: https://path.azureedge.net/media/documents/RH_ccp_screening_treatment.pdf

49. GALLAY, C. et al. Cervical cancer screening in low-resource settings: a smartphone image application as an alternative to colposcopy. In: International journal of women's health. 2017, vol. 9, pp. 455-461. ISSN 1179-1411.

50. KASPRZYK, R. et al. Creative Application to Remedy Epidemics. 2010. [Accesat 11.08.2019]. Disponibil: https://www.researchgate.net/publication/229596230_Creative_Application_to_Remedy_Epid emics

51. GAGAUZ, O. et al. Population Situation Analysis in the Republic of Moldova. CCD. Chişinau, 2016. [Accesat 11.08.2019]. Disponibil: https://moldova.unfpa.org/sites/default/files/pubpdf/PSA_engleza.pdf

52. GAGAUZ, O, PAHOMII, I. Youth health and health-risk behavior. In: Economie şi Sociologie = Economy and Sociology. 2017, nr. 4, pp. 94-105. ISSN 1857-4130.

53. HRUSCIOV, E. Population ageing determinants in the Republic of Moldova and selected European Countries. In: Economie şi Sociologie = Economy and Sociology. 2017, nr. 1-2, pp. 148-158. ISSN 1857-4130.

54. PISCHINA, T. Economic growth in the Republic of Moldova - today's challenges and opportunites. In: Economie şi Sociologie = Economy and Sociology. 2016, nr. 3, pp. 54-62. ISSN 1857-4130.

55. JARYNOWSKI, A., BUDA, A., PARADOWSKI, M.B. Modelling communities and populations: an introduction to computational social science. 2018. [Accesat 11.08.2019]. Disponibil: https://www.academia.edu/37401978/Modelling_communities_and_populations_An_introduct ion_to_computational_social_science 
56. DONOVAN, B. et al. Quadrivalent human papillomavirus vaccination and trends in genital warts in Australia: analysis of national sentinel surveillance data. In: The Lancet infectious diseases.

2011, vol. 11 (1), pp. 39-44. [Accesat 11.08.2019]. Disponibil:

https://www.ncbi.nlm.nih.gov/pubmed/21067976

57. Reproductive, Maternal and Child Health in Eastern Europe and Eurasia: A Comparative Report.

Center for Disease Control and Prevention. 2003, april. [Accesat 21.08.2019]. Disponibil: https://dhsprogram.com/pubs/pdf/OD28/00FrontMatter.pdf

58. ROSTAȘ, I. ș.a. Incluziune și excluziune socială: drepturile persoanelor care trăiesc HIV/SIDA în Republica Moldova. Institutul pentru Drepturile Omului. 2014. [Accesat 11.08.2019]. Disponibil:

http://www.crjm.org/wp-content/uploads/2014/04/IDOM.raport.incluziune.2011.rom_pdf

59. BELIK, V. et al. Natural human mobility patterns and spatial spread of infectious diseases. In: Physical Review. 2011. [Accesat 11.10.2019]. Disponibil: http://rocs.huberlin.de/papers/belik_2011a.pdf

60. ANDERSON, R.M., MAY, R.M. Infectious Diseases of Humans: Dynamics and Control. Oxford: Oxford University Press, 1992. ISBN 978-0198540403.

61. HORN, J., DAMM, O. et al. Estimating the long-term effects of HPV vaccination in Germany. In: Vaccine. 2013, vol. 31 (19), pp. 2372-2380. ISSN 0264-410X.

\section{ARTICLE HISTORY}

Received 15 October 2019

Accepted 20 November 2019 